\title{
Tail Gut Cyst - A Rare Cause of Retrorectal Mass: Case Report
}

\section{Tail Gut Kisti - Retrorektal Kitlenin Nadir Bir Sebebi: Vaka Takdimi}

\author{
Ümit Özçelik ${ }^{1}$, Hüseyin Yüce Bircan ${ }^{1}$, Halime Çevik ${ }^{2}$, Şemsi Altaner ${ }^{3}$, Alp Demirağ $\breve{g}^{1}$ \\ ${ }^{1}$ Baskent University School Of Medicine, Department Of General Surgery, Istanbul \\ ${ }^{2}$ Baskent University School Of Medicine, Department Of Radiology, Istanbul \\ ${ }^{3}$ Baskent University School Of Medicine, Department Of Pathology, Istanbul
}

Dergiye Ulaşma Tarihi: 31.07.2015 Dergiye Kabul Tarihi: 11.08.2015 Doi: 10.5505/aot.2015.03016

\section{ÖZET}

Tail gut kistleri embriyonik hindgut kalıntılarından gelişen ve retrorektal bölgede yerleşen nadir konjenital lezyonlar olup sıklıkla orta yaşlı kadınlarda perirektal semptomlarla kendilerini gösterirler. Her ne kadar tail gut kistleri benign konjenital lezyonlar olsa da nadiren malign transformasyon bildirilmiştir. Bu vaka takdiminde hastaneye 2 aydır olan asemptomatik palpabl perirektal kitle ile başvuran 48 yaşında bir bayan hastayı sunduk. Tail gut kistinin radyolojik görünümü 3 lobülden oluşmakta idi ve kombine perineal ve abdominal yaklaşım ile başarılı bir şekilde eksize edildi.

Anahtar Kelimeler: Retrorektal hamartoma, enterik kistler, perirektal kitle

\section{ABSTRACT}

Tail gut cysts are rare congenital lesions located in retrorectal area arising from the vestiges of the embryonic hindgut and often present in middle-aged women with perirectal symptoms. Although tail gut cysts are usually benign congenital lesions, malignant transformation has been rarely reported. In this case report we present a 48year-old woman who was admitted to hospital with an asymptomatic palpable perirectal mass for two months. The radiological appearance of tail gut cyst was three lobulated and it was successfully excised with combined perineal and abdominal approaches.

Key words: Retrorectal hamartoma, enteric cysts, perirectal mass

\section{Background}

Retrorectal hamartomas or tail gut cysts are rare congenital lesions located in retrorectal area arising from the vestiges of the embryonic hindgut and often present in middle-aged women with perirectal symptoms $(1,2)$. Tail gut cysts have also been referred to as retrorectal cyst hamartoma, cyst of postanal intestine, tail gut vestiges, and rectal cyst (2).

Developmental cysts in the retrorectal area can be classified as epidermoid cyst, rectal duplication cyst and cystic hamartoma (tail gut cyst), according to the origin and histopathological features (3).

Although tail gut cysts are usually benign congenital lesions, malignant transformation has been rarely reported (3). Also these cysts have occasionally shown retrorectal abscess and rectal fistula (2).Therefore, early diagnosis is important. Tail gut cysts should be excluded from other lesions which may occur in the retrorectal area including teratomas, epidermal cysts, rectal duplication cysts, anal gland cysts, and anal gland carcinomas (2).

Because they are rare, differential diagnosis of these lesions may be difficult for Adressforcorrespondence: Uzm. Dr. Ümit Özçelik

e-mali: dr_umit_ozcelik@yahoo.com

Available at www.actaoncologicaturcica.com

Copyright $\mathbb{C}$ Ankara Onkoloji Hastanesi the pathologist. Tail gut cyst develops from embryological hindgut and usually occurs as a multiloculated cyst lined by squamous, transitional, or glandular epithelium.

\section{Case Report}

A 48 year-old woman was admitted to hospital with an asymptomatic palpable perirectal mass for two months. In digital rectal examination a perirectal $5 \times 3 \mathrm{~cm}$ smooth mass was detected. A computed tomography (CT) scan of abdomen/pelvis showed a perirectal three-lobular cystic mass from perianal area to pelvis and measured as $5,1 \mathrm{~cm} \mathrm{x} 3,6 \mathrm{~cm}, 4,2 \mathrm{x}$ $3,4 \mathrm{~cm}$ and $8 \times 5,1 \mathrm{~cm}$ respectively. Also a $4 \mathrm{x}$ $3,4 \mathrm{~cm}$ right ovarian cyst was detected by $\mathrm{CT}$ scan (Figure 1). There was no obvious communication between the cysts and rectum. An abdominal magnetic resonance imaging (MRI) was also performed and showed similar findings (Figure 2, 3, 4).

The three-lobular cyst was totally excised with combined abdominal and perineal approaches (Picture 1 and 2). The patient was discharged at the postoperative $4^{\text {th }}$ day without complications. Histopathologic examination showed multilocular cystic lesions with 


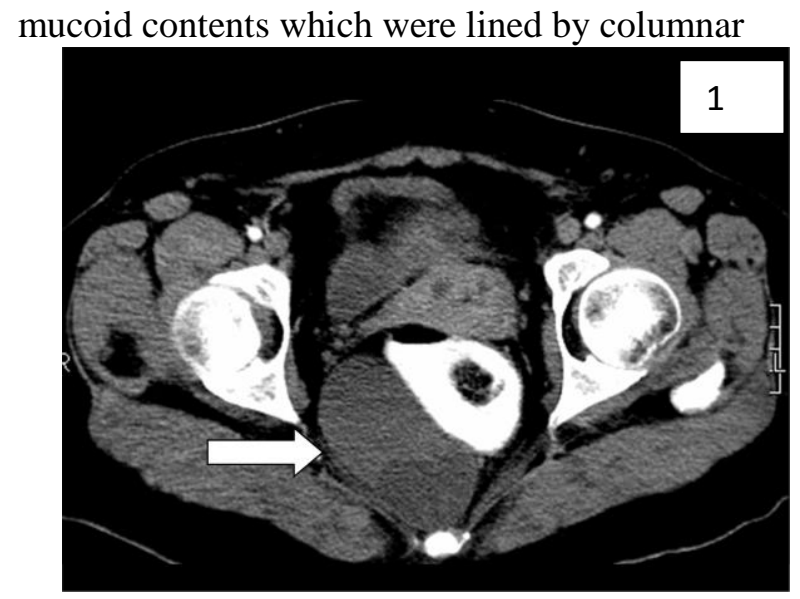

and squamous epithelium supported by a
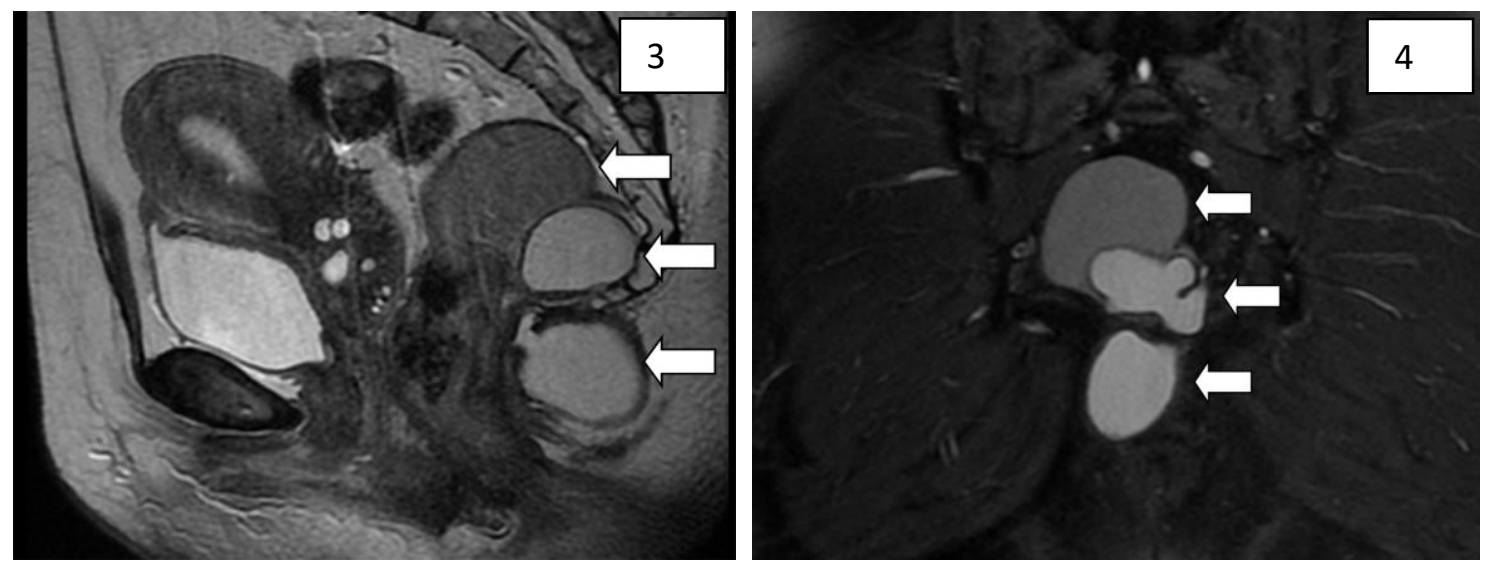

Figure 1: Right perirectal tail gut cyst. There was no obvious communication between the cyst and rectum and no bony destruction of the coccyx (postcontrast abdomen CT image). Figure 2: Infracoccygeal hypointense cystic lesion (axial postcontrast fat sat T1-weighted MRI image). Figure 3: Presacral, precoccygeal and infracoccygeal hyperintense cystic lesions (sagittal T2-weighted MRI image). Figure 4: Presacral, precoccygeal and infracoccygeal hyperintense cystic lesions (coronal fat sat T2-weighted MRI image).

fibroconnective tissue and skeletal muscle fibers and surrounding inflammatory cell infiltration including lymphoctes, histiocytes and plasma cells and foreign body-type giant cells (Picture 3 and 4).

\section{Discussion}

Tail gut cysts are rare developmental cysts that usually occur in the retrorectal space and are categorized under enteric cysts $(1,2,3$, $4)$. They are thought to arise from postanal primitive gut remnants because of the failure of regression of tailgut $(2,4)$. They are predominantly located in the presacral retrorectal space with anterior rectal displacement but in our case it was located in right perirectal area, displacing the rectum and anal canal to the left like Prasant et al.'s previous report $(1,6)$.

Teratomas, epidermal cysts, rectal duplication cysts, anal gland cysts and anal gland carcinomas should be considered in differential diagnosis $(2,7)$.
Tail gut cysts can be seen in all range groups but they are more common in middleaged women $(1,2,3)$. Most of the patients are asymptomatic and usually they are diagnosed incidentally (2). Symptoms are frequently related to compressive effects of mass as rectal fullness, constipation, abdominal and back pain, pain on defecation, rectal bleeding, and urinary frequency (2). Infection of the cyst, recurrent abcess and anal fistulas can also be seen $(1,2)$.

Most of the tail gut cysts are benign and rarely malignant transformation may occur $(1,2,8)$. Malignancies associated with tail gut cysts are adenocarcinomas, carcinoid tumors, neuroendocrine carcinomas, endometrioid carcinoma, adenosquamous carcinoma, squamous cell carcinoma and sarcoma (2, 4, 9, 10). Tail gut cysts should be assessed for malignancy and they should be removed when diagnosed because precise diagnosis can only be made by histopathologic examination after surgical removal (2). Needle biopsy is not 

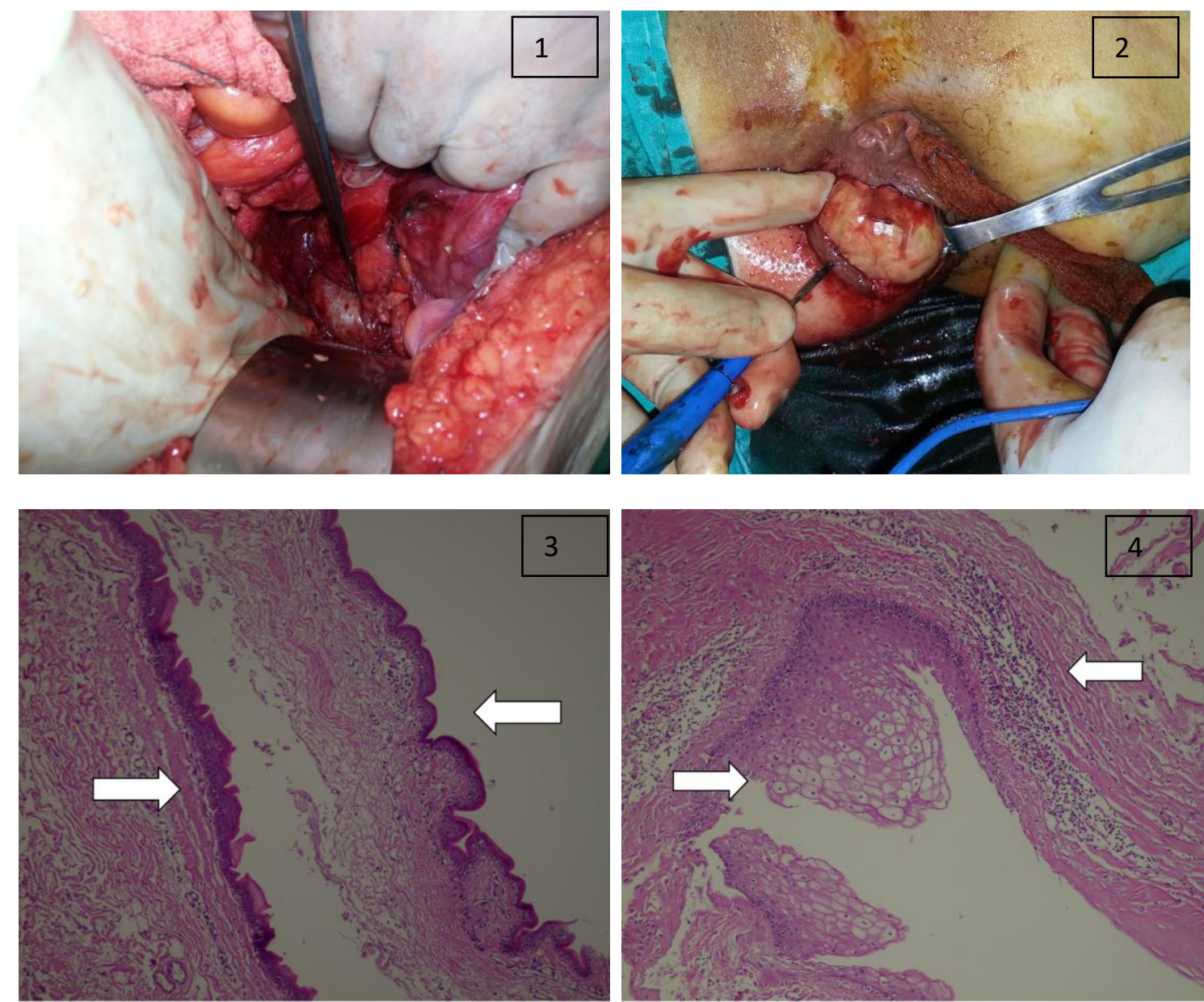

Picture 1: Perirectal tail gut cyst (abdominal approach). Picture 2: Perianal tail gut cyst (perineal approach). Picture 3: Cyst wall, lined by columnar epithelium (H\&E, x100).Picture 4: Mature squamous epithelium and surrounding inflammatory cell infiltration (H\&E, x100).

advised because of potential false negative results and the risk of spillage into the pelvic cavity and seeding of the biopsy tract (2). It can only be considered for patients with high surgical risks (2).

Imaging modalities can be helpful in the differential diagnosis. Tail gut cysts are seen as well defined homogenous retrorectal masses in CT scan and most of them are multiloculated (2). They can appear more solid because of the keratinous or inflammatory debris within the cyst (2). Intralesional calcifications and bony destruction of coccyx or sacrum favor the diagnosis of teratoma or malignancy (2). They appear as hypointense lesions on T1-weighted MRI images and hyperintense lesions on T2-weighted MRI images (2). Irregular wall thickening and intermediate signal intensity on both $\mathrm{T} 1$ and T2-weighted MRI images can be clues of malignancy but MRI imaging is not the best imaging modality for differentiating malignancy (2).

The prognosis of tail gut associated malignancies varies due to the factors such as time of the diagnosis, completeness of resection, tumor histology and grade (2). Adenocarcinomas have poor prognosis due to local recurrence and metastases than neuroendocrine or carcinoid tumors (2). Because of the difficulty on determining the tail gut cyst is benign or malignant and allowing definitive treatment of possible malignancy; early surgical removal is recommended (2).

In conclusion; it is important to consider tail gut cysts in the differential diagnosis of perirectal cysts and surgical intervention is needed when it is diagnosed in order to exclude malignancy.

\section{Conflict of Interest: None}




\section{References}

1. Prasant P, Uttam G, and Peacock M. Retrorectal hamartoma: A 'tail' of two cysts. Indian J Radiol Imaging 2010;20(2):129-31

2. Chhabra S, Wise S, Maloney-Patel N, Rezac C, Poplin E. Adenocarcinoma associated with tail gut cyst. J Gastrointest Oncol 2013;4(1):97-100

3. Dahan H, Arrivé L, Wendum D, Docou le Pointe H, Djouhri H, Tubiana JM. Retrorectal developmental cysts in adults: Clinical and radiologichistopathologic review, differential diagnosis and treatment. Radiographics 2001;21:575-84

4. Cho BC, Kim NK, Lim BJ, et al. A carcinoembryonic antigen-secreting adenocarcinoma arising in tailgut cyst: clinical implications of carcinoembryonic antigen. Yonsei Med J 2005;46:555-61

5. Kang JW, Kim SH, Kim KW, Moon SK, Kim CJ, Chi JG. Unusual perirenal location of a tailgut cyst. Korean J Radiol 2002;3:267-70
6. Yand DM, Park $\mathrm{CH}$, Jin W, et al. Tailgut cyst: MRI evaluation. AJR Am J Roentgenol 2005;184:1519-23

7. Graadt van Roggen JF, Welvaart K, de Roos A, Offerhaus GJ, Hogendoorn PC. Adenocarcinoma arising within a tailgut cyst: clinicopathological description and follow up of an unusual case. J Clin Pathol 1999;52:310-2

8. Prasad AR, Amin MB, Randolph TL, Lee CS, Ma CK. Retrorectal cystic hamartoma: Report of 5 cases with malignancy arising in 2. Arch Pathol Lab Med 2000;124:725-9

9. Gönül II, Bağlan T, Pala I, Menteş B. Tailgut cysts: diagnostic challenge for both pathologists and clinicians. Int J Colorectal Dis 2007;22:1283-5

10. Menteş BB, Kurukahvecioğlu O, Ege B, et al. Retrorectal tumors: a case series. Turk J Gastroenterol 2008;19:40-4 